\title{
FACTORS INFLUENCING THE HRD CLIMATE OF AN ORGANIZATION
}

\author{
Neeraj Kumari ${ }^{1}$ \\ 'Assistant Professor (Humanities \& Management) Faculty of Engineering \& Technology Manav Rachna International University \\ Faridabad, India
}

\begin{abstract}
The aim of the study was to find out which factor (s) influence the HRD climate of the company. The descriptive research design was under taken with the help of the structured questionnaire to study the OCTAPACE culture of Spanco Ltd. which was based on the responses of the various levels of employees working in it. Thesample consistsof 59 employees. Employees believe that the top management gives importance to the human resource and all the employees are treated humanely in the organization. The climate is also favourable in terms of employee being handled with care by seniors as they understand the mistake and do not take any strict disciplinary action such as punishing or discouraging.There is also a fair share of management involvement in making work enjoyable. Good part of Spanco regarding HRD is that top management understands the importance of human resource and actually translates that realization into day to day practice and HR policies.In conclusion, the overall HRD climate of Spanco is encouraging. There is a keen interest of top management in HRD and there is a high team spirit and employees take training seriously. Organizational belonging of employees is also high. Despite of such positive base for HRD, HRD mechanism needs improvisation in a systematic way.
\end{abstract}

Keywords: Authenticity, Autonomy, Confrontation, HR policies, Openness, Trust.

Received: 26 August 2013/ Revised: 20 September 2013/ Accepted: 23 September 2013/ Published: 25 September 2013

\section{INTRODUCTION}

If we need to find a way to develop employees in order to become effective contributors to the goals of an organization, we need to have a clear view of what an effective contribution would look like. The use of personal capacities can be very helpful in describing the way in which an effective employee should operate and behave, but there can be no general prescription of an effective employee. Effectiveness will differ with organizational context, and on whose perspective we are adopting. The matter of what, finally, makes an effective employee is a combination of personality, 
natural capabilities, developed skills, experience and learning. The process of enhancing an employee's present and future effectiveness is called development.

\subsection{Meaning of HRD Climate}

HR means employees in organisation, who work to increase the profit for organisation. Development, it is acquisition of capabilities that are needed to do the present job, or the future expected job. After analyzing Human Resource and Development we can simply stated that, HRD is the process of helping people to acquire competencies. Climate, this is an overall feeling that is conveyed by the physical layout, the way employees interact and the way members of the organisation conduct themselves with outsiders.

"Organisational climate is a set of characteristics of an organisation which are referred in the descriptions employees make of the policies, practices and conditions which exist in the working environment".

An organisation became dynamic and growth oriented if their people are dynamic and proactive. Through proper selection of people and by nurturing their dynamism and other competencies an organisation can make their people dynamic and pro-active. To survive it is very essential for an organisation to adopt the change in the environment and also continuously prepare their employees to meet the challenges; this will have a positive impact on the organisation.

\subsection{What is needed to Develop Organisational Climate in an Organisation?}

Top to Bottom Effort: Organisation is considered to be complete organisation after including top authority to bottom line of workers. And whenever we talk about development at organisational level effort is needed from top level to bottom level. Top authority should not have thinking in their mind that their task is to only take decisions but they should also emphasized on proper implementation of decision by adopting various controlling technique. Bottom level workers should have loyal mind-set towards their organisation. Bottom level workers have to work with dedication. They should have realisation that organisation is their organisation. To prepare Human Resource Development Climate, Manager and Supervisor's responsibilities are more or we can say that they are the key players. Manager and Supervisors have to help the employees to develop the competencies in the employees. To help the employees at lower level they need to updated properly and they need to share their expertise and experience with employees.

Faith upon Employee's: In the process of developing HRD Climate employer should have faith on its employee's capabilities. Means whatever amount is invested that should be based on development of employees. Top management should trust the employees that after making huge effort to develop employees, employees will work for the well being of organisation and for human being also.

Free expression of Feelings: Whatever Top management feels about employees they have to express to employees and whatever employees think about top management it must be express in 
other words we can say that there should not be anything hidden while communication process. Clear communication process will help to establish the HRD Climate.

Feedback: Feedback should be taken regularly to know the drawbacks in system. This will help to gain confidence in employees mind. Employee will trust on management and he can express his opinion freely which is very good for HRD Climate. Feedback will help to remove the weakness.

Helpful nature of employee's: Whenever we talk about $100 \%$ effort then we have to talk about employee's effort too. Nature of employee's should be helping for management and for its colleagues. They should be always read to help to customers too.

Supportive personnel management: Personnel policies of organisation should motivate employees to contribute more from their part. Top management's philosophy should be clear towards Human Resource and its well being to encourage the employees.

Encouraging and risk taking experimentation: Employee's should be motivated by giving them authority to take decision. This concept is risky but gradually it will bring expertise in employee's to handle similar situation in future. It will help to develop confidence in employees mind. Organisation can utilize and develop employees more by assigning risky task.

Discouraging stereotypes and favouritism: Management need to avoid those practices which lead to favouritism. Management and Managers need to give equal importance. Those people who are performing good they need to appreciate and those who are not performing well they need to be guided. Any kind of partial behaviour should be avoided.

Team Spirit:- There must be feeling of belongingness among the employees, and also willingness to work as a team.

\section{LITERATURE REVIEW}

The study of organizations can be traced to ideas of Socrates and Aristotle in $400 \mathrm{BC}$ and is comprised of various theoretical perspectives on organizational function, structure, and processes. Within these perspectives, the concept of organizational culture has been around for only 25 years but has challenged the dominant view of organizations as "rational-utilitarian institutions whose purpose is to accomplish established goals" (Shafritz et al., 2005). Instead, organizational dynamics, structure, and decisions are viewed to be constructed by its individual members and groups through consensus, conflict, or paradox (Martin, 2002).

Three authors discussed organizational culture in terms of a business orientation. Connell, Papke, (Connell et al., 2003) researched factors that affected organizational transformation from "an order-taking/operational culture to a sales-and-service culture" (p. 531)or "high-performance sales culture" (p. 530). In the study of TQM, organizational change, and continuous improvement, Walton and Basra (2001) described organizational culture as a shift from operations or product oriented to customer and market oriented.

Five manuscripts discussed sub cultures within an organization-wide culture and characterized the relationships between the former and the latter from harmonic to disenfranchise. For example, Powell (1997) argued that organizational culture "often develops 
sub-cultures which, in turn, create dissonance and disharmony" (paper 6-1). Hansen and Kahnweiler (1994) suggest that "occupational cultures form around the belief that members have the exclusive right to perform a given set of interrelated tasks" (p. 72) and reject the idea of a harmonic organizational culture.

Sub-cultures can co-exist as "an integrated cultural confederation" only when an organization “acknowledges differences and builds upon similarities” (p. 77). Distances between a sub-culture and the main culture decrease organizational effectiveness, so organization-wide culture aims to reduce such distances and build harmony within the organization.

Ouchi (1981), Peters and Waterman (1982), and Deal and Kennedy (1982) explored how organizational culture contributes to business success. As their works turned into bestsellers, organizational culture became a frequent headline in popular business literature and a tool for businesses to increase their competitiveness in the global market (Denison, 1990). In the 1970s, Japan's phenomenal business success and the decrease in U.S. production moved researchers to re-examine knowledge on organizational management. Organizational culture became praised for the successes of Black \& Decker and Apple or for the downfalls of Sears and General Motors (O’Reilly, 1989).

Little understanding of how it works in practice (Alvesson, 2002) and a need for theory development stimulate research of this phenomenon in the fields of management, anthropology, and organizational studies. These and other disciplines (e.g., psychology, organizational behavior) constitute a multidisciplinary foundation of human resource development (HRD) (Hatcher, 2000). For example, organization theory/behavior constitutes a core curriculum content area at $55 \%$ of graduate HRD programs in the U.S. (Kuchinke, 2001). This led us to wonder what research on organizational culture has been conducted in the field of HRD. Such investigation can contribute to the discussion of the scope and multidisciplinary nature of the field and its relationship to business and organizational practice. The purpose of this research was to find out how organizational culture has been studied by HRD researchers. Two questions guided the study: (a) How is organizational culture defined? and (b) What are the purposes for studying organizational culture?

Turnbull (2001) researched the effect of a culture change program on employee beliefs, values, and self-identity. The program invoked such unplanned feelings as frustration, mistrust, embarrassment, or fear to be manipulated. Maria and Watkins (2001) investigated whether employee perceptions of learning culture and innovation affect their use of innovation.

\section{RESEARCH METHODOLOGY}

\subsection{Objectives of the study}

- To understand the General HRD Climate of the Organization

- To see the OCTAPACE culture of the Organization

- To find out which factor (s) influence the HRD climate of the company 


\subsection{Research Design}

Descriptive Research Design: A descriptive research design was under taken with the help of the structured questionnaire to study the OCTAPACE Culture of Spanco Ltd. which was based on the responses of the various levels of employees working in it. The Questionnaire was a standardized Questionnaire prepared by T.V Rao

Exploratory Research Design: It was used to establish priorities in studying the competing explanations of the phenomenon.

\subsection{Sample Size}

For studying the OCTAPACE culture of Spanco Ltd, 70 copy of the questionnaire were distributed to the various employees'. Out of 70 employees' I could get 59 valid filled questionnaires.

\section{DATA ANALYSIS AND INTERPRETATIONS}

\subsection{Parameter 1 Openness}

Table-1. Overall Openness

\begin{tabular}{|c|c|c|}
\hline & Mean & $\begin{array}{l}\text { Std. } \\
\text { Deviation }\end{array}$ \\
\hline $\begin{array}{l}\text { Free interaction among employees, each respecting others, } \\
\text { feelings, competence and sense of judgment }\end{array}$ & 2.8475 & 0.98733 \\
\hline $\begin{array}{l}\text { Genuine sharing of information, feelings and thoughts in } \\
\text { meetings }\end{array}$ & 2.7288 & 0.8752 \\
\hline $\begin{array}{l}\text { Free discussion and communication between seniors and } \\
\text { subordinates }\end{array}$ & 2.8305 & 1.11653 \\
\hline Effective managers put lid on their feelings & 2.1864 & 0.68165 \\
\hline $\begin{array}{l}\text { Free and frank communication between various helps in solving } \\
\text { problems }\end{array}$ & 3.0169 & 1.12175 \\
\hline Valid N (list-wise) & & \\
\hline
\end{tabular}

Figure-1.

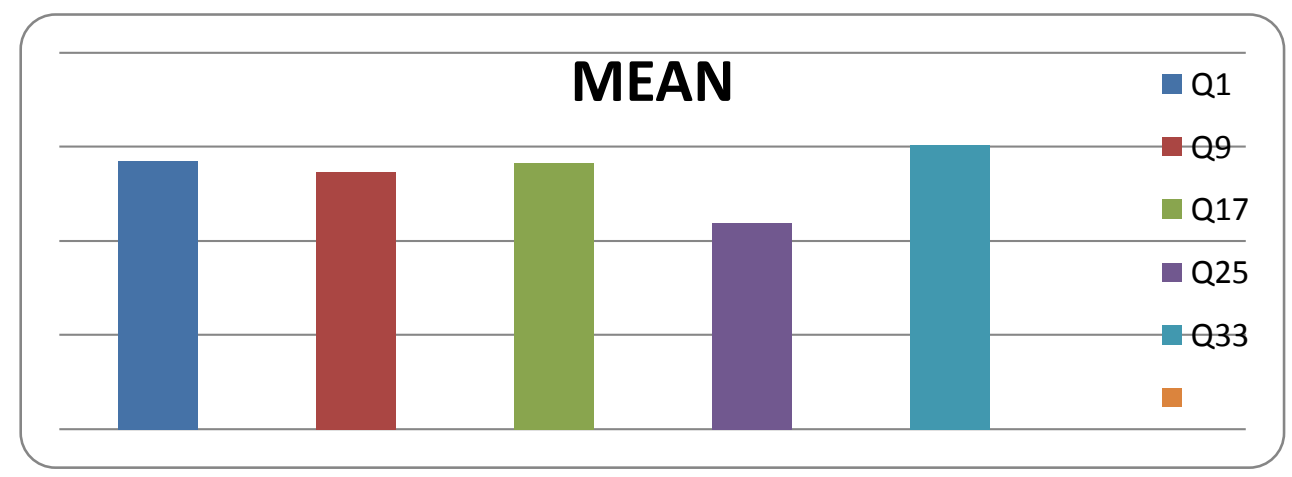

Interpretations: The grand mean of this parameter is 2.722 which clearly show that most of the people believed that openness is given a fairly high value in the organisation though some also 
believed that it's given a rather low value. The bar graph clearly shows that most of the people agree that free and frank communication between various levels helps in solving problems is given high value in the organisation. While genuine sharing of information, feelings and thoughts in meetings, free discussion and communication between seniors and subordinates and free interaction among employees, each respecting others, feelings, competence and sense of judgment parameters were given a slightly low rating. But only some people in the organisation share the belief that effective managers put lid on their feelings.

\subsection{Parameter 2 Confrontation}

Table-2. Overall Confrontation

\begin{tabular}{lll}
\hline & Mean & \multicolumn{1}{c}{$\begin{array}{l}\text { Std. } \\
\text { Deviation }\end{array}$} \\
\hline Facing and not shying from problems & 2.8814 & 0.87266 \\
\hline $\begin{array}{l}\text { Going deeper rather than doing surface-analysis of } \\
\text { interpersonal problems }\end{array}$ & 2.7458 & 0.90198 \\
\hline Facing challenges inherent in the work situation & 3 & 0.85096 \\
\hline Pass the buck tactfully whenever there is a problem & 1.8644 & 0.8399 \\
\hline $\begin{array}{l}\text { Surfacing problems is not enough ;we should find the } \\
\text { solutions }\end{array}$ & 3.3051 & 0.72526 \\
\hline Valid N (list-wise) & \\
\hline
\end{tabular}

Figure-2.

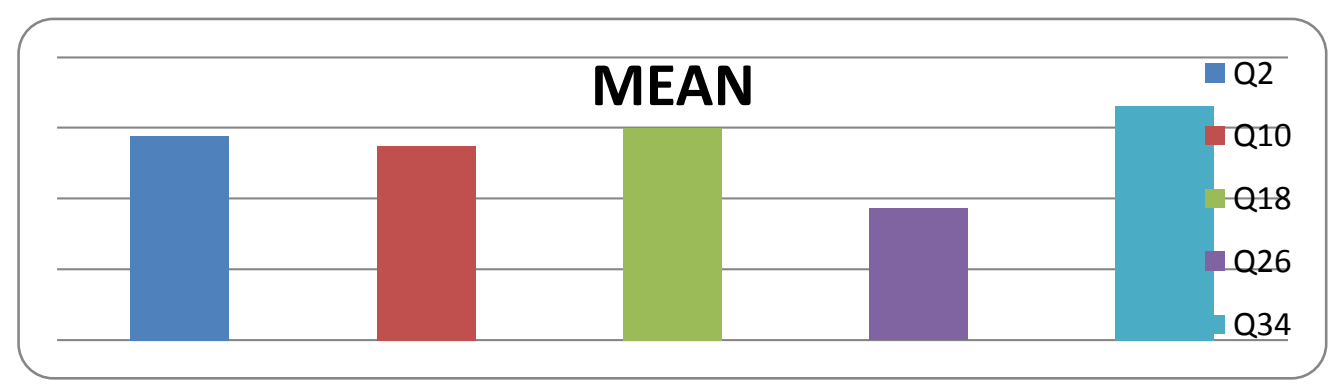

Interpretaions: The grand mean shows that most of the people in the organisation believe that value given to confrontation lies between rather low to fairly high.Facing and not shying from problems, going deeper rather than doing surface-analysis of interpersonal problems and facing challenges inherent in the work situation parameters were given a fairly high rating. Surfacing problems is not enough; we should find the solution is the most widely shared belief in the organisation. And pass the buck tactfully whenever there is a problem is a belief that most people feel that only a few or none has this belief. 


\subsection{Parameter 3 Trust}

Table-3. Overall Trust

\begin{tabular}{lcc}
\hline & Mean & Std. Deviation \\
\hline $\begin{array}{l}\text { Offering moral support and help to employees and colleagues } \\
\text { in crisis }\end{array}$ & 3 & 0.90972 \\
\hline Interpersonal contact and support among people & 2.8136 & 0.75372 \\
\hline $\begin{array}{l}\text { Confiding in seniors without fear and they will misuse the } \\
\text { trust }\end{array}$ & 2.7458 & 0.8629 \\
\hline Trust begets trust & 3.2034 & 0.76066 \\
\hline When the chips are down you have to fend for yourself & 2.0169 & 0.77663 \\
\hline Valid N (list wise) & & \\
\hline
\end{tabular}

Figure-3.

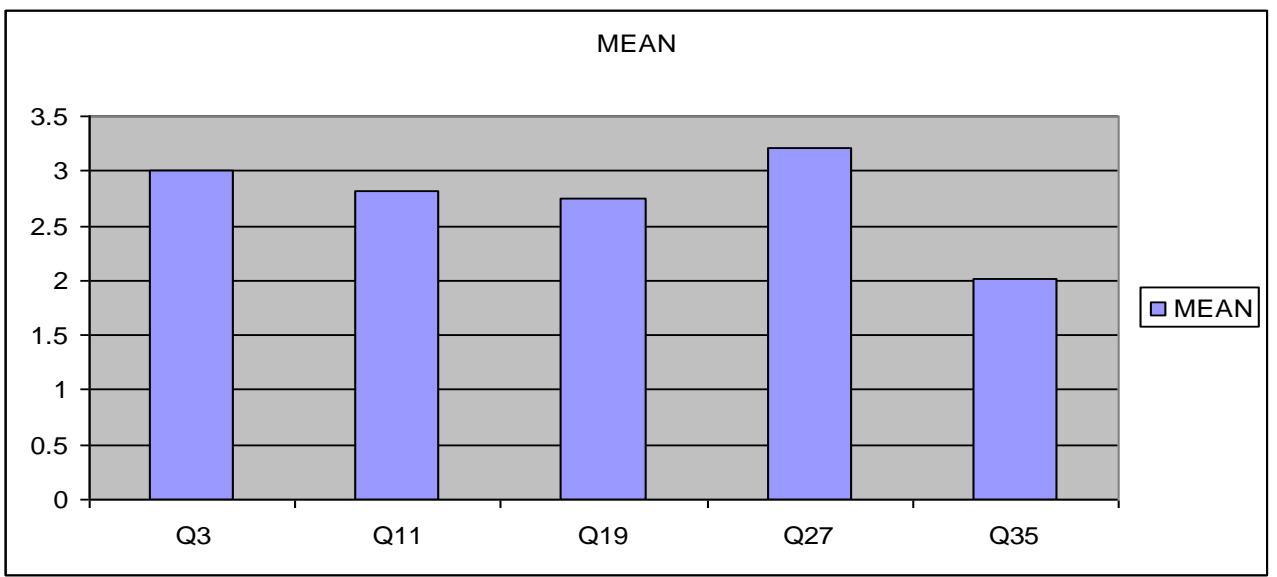

Interpretations: Trust as a parameter was given a fairly high rating by the employees. Most people believed that parameters like "offering moral support and help to employees and colleagues in crisis", "interpersonal contact and support among people" and "confiding in seniors without fear and they will misuse the trust" are given fairly high value in the organisation. "Trust begets trust" is the very widely shared belief of the organisation. And "When the chips are down you have to fend for yourself" is a belief that only a few people share.

\subsection{Parameter 4 Authenticity}

Table-4. Overall Authencity

\begin{tabular}{lll}
\hline & Mean & $\begin{array}{l}\text { Std. } \\
\text { Deviation }\end{array}$ \\
\hline $\begin{array}{l}\text { Congruity between feelings and expressed behaviour (minimum } \\
\text { gap between what people say and what people do) }\end{array}$ & 2.5932 & 0.76831 \\
\hline $\begin{array}{l}\text { Tactfulness , smartness and even a little manipulation to get } \\
\text { things done }\end{array}$ & 1.8644 & 0.86018 \\
\hline Owning up to mistakes & 2.7288 & 0.84752 \\
\hline Telling a polite lie preferable to telling the unpleasant truth & 2.5424 & 0.89678 \\
\hline People generally are what they appear to be & 2.6949 & 0.83572 \\
\hline Valid N (list-wise) & & \\
\hline
\end{tabular}


Figure-4.

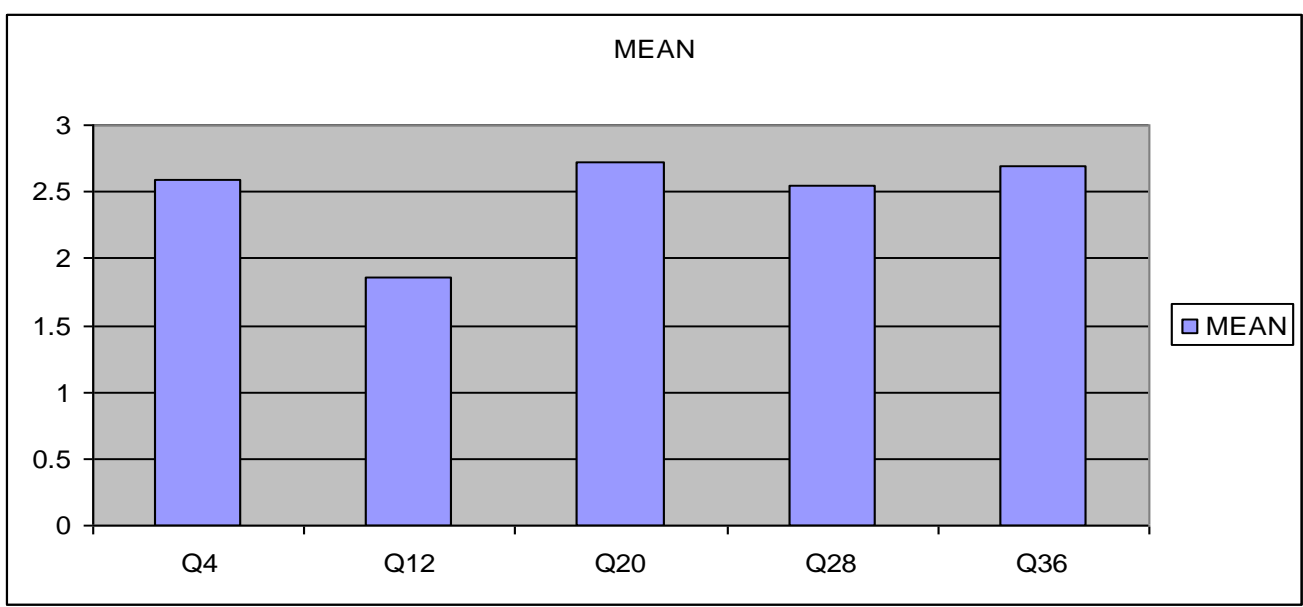

Interpretations: Grand mean of the authenticity shows that it is given a rather low value in the organisation. Parameters like "Congruity between feelings and expressed behaviour", "Telling a polite lie preferable to telling the unpleasant truth" and "People generally are what they appear to be" are beliefs that are given a fairly high value. And "Tactfulness, smartness and even a little manipulation to get things done" is given a low value. Moreover "Owning up to mistakes" is a belief that is given high value in the organisation.

\subsection{Parameter 5 Proaction}

Table-5. Overall Proactive

\begin{tabular}{lll}
\hline & Mean & $\begin{array}{l}\text { Std. } \\
\text { Deviation }\end{array}$ \\
\hline Preventive actions on most matters & 3.02 & 0.82 \\
\hline $\begin{array}{l}\text { Seniors encouraging their subordinates to think about their } \\
\text { development and take action in that direction }\end{array}$ & 2.7458 & 1.1536 \\
\hline $\begin{array}{l}\text { Considering both positive and negative aspects before taking } \\
\text { actions. }\end{array}$ & 3.1695 & 0.9126 \\
\hline Prevention is better than cure & 3 & 0.89056 \\
\hline A stitch in time saves nine & 3.0169 & 0.77663 \\
\hline Valid N (listwise) & & \\
\hline
\end{tabular}


Figure-5.

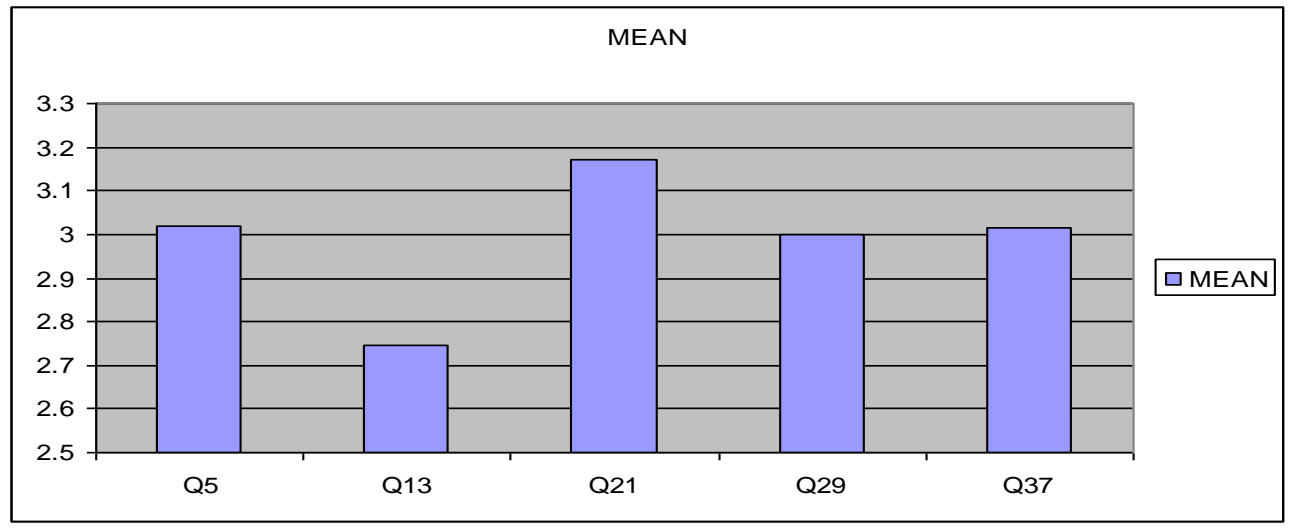

Interpretations: It is clearly evident that most of the people in the organisation believe that being proactive is the highly valued parameter. "Preventive actions on most matters", "Prevention is better than cure" and "A stitch in time saves nine" are the most highly valued and "Seniors encouraging their subordinates to think about their development and take action in that direction" is the value which is given slightly low rating.

\subsection{Parameter 6 Autonomy}

Table-6. Overall Autonomy

\begin{tabular}{lll}
\hline & Mean & $\begin{array}{l}\text { Std. } \\
\text { Deviation }\end{array}$ \\
\hline Taking independent action relating to their jobs & 3.0169 & 0.81983 \\
\hline Close supervision of, and directing employees on action & 2.7288 & 0.73884 \\
\hline $\begin{array}{l}\text { Obeying and checking with seniors rather than acting on your } \\
\text { own. }\end{array}$ & 2.9661 & 0.8087 \\
\hline Freedom to employees breeds indiscipline & 2.9661 & 0.8087 \\
\hline $\begin{array}{l}\text { A good way to motivate employees is to give them autonomy to } \\
\text { plan their work }\end{array}$ & 3.0169 & 0.90003 \\
\hline Valid N (list wise) & & \\
\hline
\end{tabular}

Figure-6.

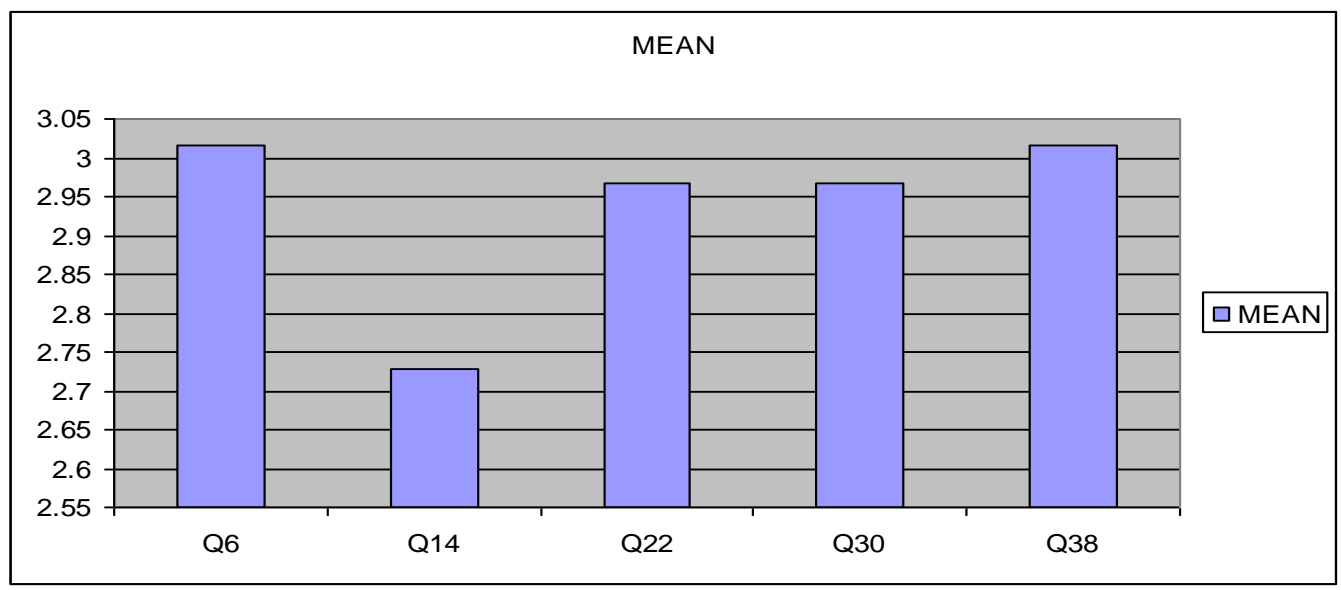


Interpretations: It's clearly evident that autonomy is the parameter which is given a high value in the organisation. People believe that a good way to motivate employees is to give them autonomy to plan their work. Most of the people believe that "taking independent action relating to their jobs" is the highly value in the organisation. "Close supervision of, and directing employees on action" and "Obeying and checking with seniors rather than acting on your own" are given fairly good value.

\subsection{Parameter 7 Collaboration}

Table-7. Overall Collaboration

\begin{tabular}{lll}
\hline & Mean & $\begin{array}{l}\text { Std. } \\
\text { Deviation }\end{array}$ \\
\hline Team work and team spirit & 2.7627 & 0.8578 \\
\hline Accepting and appreciating help offered by others & 3.1356 & 0.81912 \\
\hline $\begin{array}{l}\text { Performing immediate tasks rather than being concerned about } \\
\text { large organization goals. }\end{array}$ & 2.3559 & 0.9959 \\
\hline Usually, emphasis on team work dilutes individual accountability & 2.4068 & 1.10045 \\
\hline $\begin{array}{l}\text { Employee's involvement in developing an organization's mission } \\
\text { and goals contributes to productivity }\end{array}$ & 2.9492 & 1.15107 \\
\hline Valid N (list-wise) & \multicolumn{2}{l}{} \\
\hline
\end{tabular}

Figure-7.

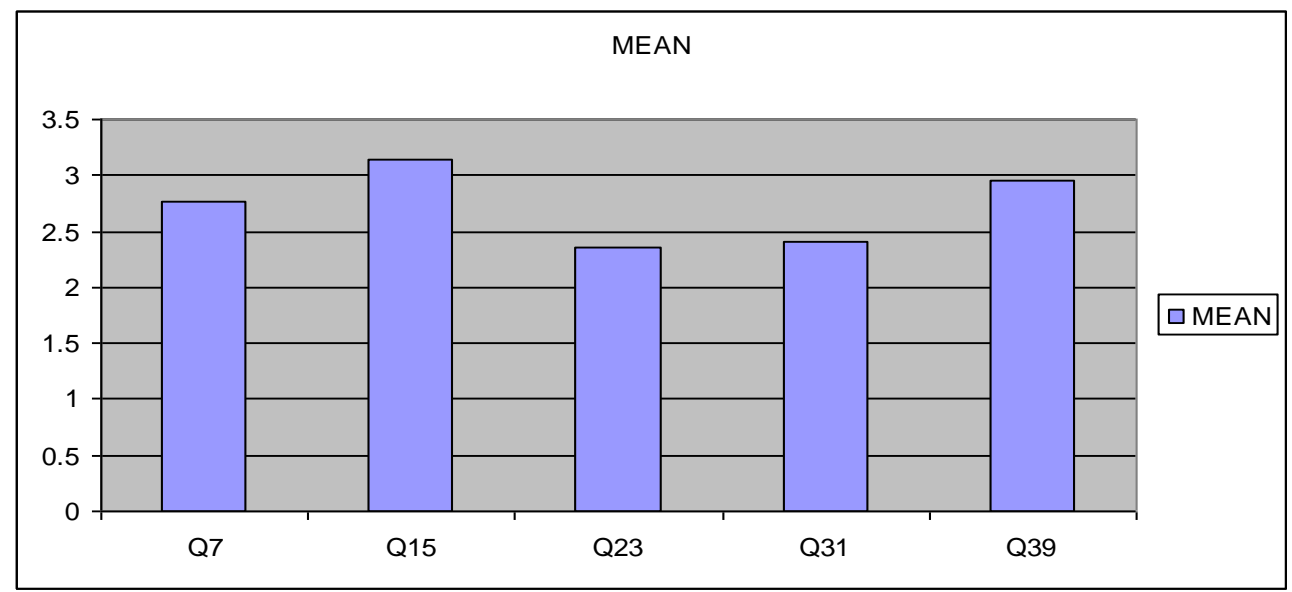

Interpretations: The grand mean shows that most people agree that collaboration is a highly valued in the organisation. "Team work and team spirit" and "Usually, emphasis on team work dilutes individual accountability" and "Employee's involvement in developing an organization's mission and goals contributes to productivity" are given fairly high value in the organisation. People believe that parameter "Performing immediate tasks rather than being concerned about large organization goals" is not given so much value in the organisation. 


\subsection{Parameter 8 Experimentation}

Table-8. Overall Experimentation

\begin{tabular}{lll}
\hline & Mean & Std. Deviation \\
\hline Trying out innovative ways of solving problems & 2.6949 & 0.79338 \\
\hline $\begin{array}{l}\text { Encouraging employees to take a fresh look at how things are } \\
\text { done }\end{array}$ & 2.6949 & 0.95148 \\
\hline $\begin{array}{l}\text { Making genuine attempts to change behaviour on the basis of } \\
\text { feedback. }\end{array}$ & 2.4407 & 0.95179 \\
\hline $\begin{array}{l}\text { Thinking out and doing new things tones up the } \\
\text { organization's vitality }\end{array}$ & 3.1525 & 0.88695 \\
\hline $\begin{array}{l}\text { In today's competitive situations, consolidation and stability } \\
\text { are more important than experimentation }\end{array}$ & & 1.9322 \\
\hline \begin{tabular}{l} 
Valid N (list wise) \\
\hline
\end{tabular}
\end{tabular}

Figure-8.

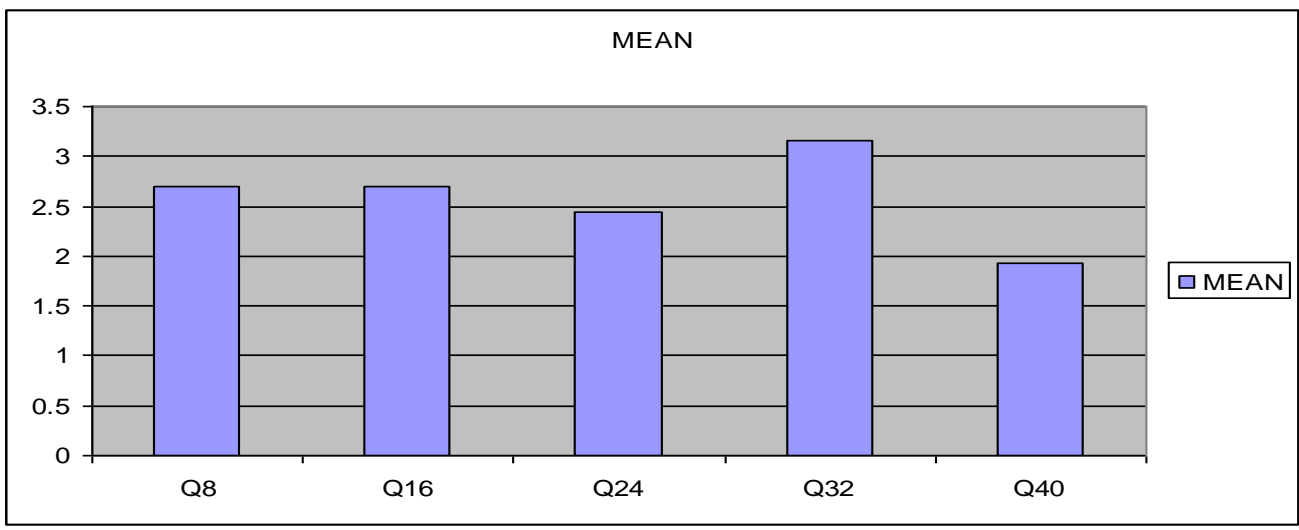

\subsection{Factor Analysis}

Table-9. Factor analysis

\begin{tabular}{lll}
\hline & Initial & Extraction \\
Total Openness & 1.000 & .383 \\
Total Confrontation & 1.000 & .609 \\
Total Trust & 1.000 & .520 \\
Total Authenticity & 1.000 & .708 \\
Total Proaction & 1.000 & .583 \\
\hline Total Autonomy & 1.000 & .586 \\
\hline Total Collaboration & 1.000 & .670 \\
\hline Total Experimentation & 1.000 & .679 \\
\hline
\end{tabular}

Extraction Method: Principal Component Analysis.

Interpretations: It's very clear that experimentation is very important parameter. Mostly people "Offering moral support and help to employees and colleagues in a crisis", "Encouraging employees 
to take a fresh look at how things are done" and "Making genuine attempts to change behaviour on the basis of feedback" are given a rather low value. "Thinking out and doing new things tones up the organization's vitality" is the belief which is widely shared. And "In today's competitive situations, consolidation and stability are more important than experimentation" is a belief which only a few or none have.

Table-10. Total Variance Explained

\begin{tabular}{lllllll}
\hline & \multicolumn{2}{l}{ Initial Eigenvalues } & \multicolumn{3}{l}{ Extraction Sums of Squared Loadings } \\
\cline { 2 - 7 } Component & Total & \% of Variance & Cumulative \% & Total & \% of Variance & Cumulative \% \\
\hline 1 & 2.190 & 27.373 & 27.373 & 2.190 & 27.373 & 27.373 \\
\hline 2 & 1.438 & 17.972 & 45.345 & 1.438 & 17.972 & 45.345 \\
\hline 3 & 1.110 & 13.881 & 59.226 & 1.110 & 13.881 & 59.226 \\
\hline 4 & .904 & 11.304 & 70.530 & & & \\
\hline 5 & .706 & 8.831 & 79.361 & & & \\
\hline 7 & .618 & 7.724 & 87.085 & & & \\
\hline 8 & .555 & 6.934 & 94.020 & & & \\
\hline
\end{tabular}

Extraction Method: Principal Component Analysis.

Interpretations: The Total Variance Explained table above shows the Eigen values which are the proportion of total variance in all the variables which is accounted by that factor. This table shows that out of the 8 parameters selected for studying OCTAPACE in Spanco, only 3 parameters were found to be having Eigen values greater than 1. So $59 \%$ of the data can be represented by these three parameters.

These were extracted on the basis of Eigen values. Those factors having Eigen values greater than one were only extracted by applying this statistical tool.

Table-11. Component Matrix ${ }^{a}$

\begin{tabular}{llll}
\hline \multicolumn{4}{c}{ Component } \\
& 1 & 2 & 3 \\
Total Openness & .534 & -.156 & -.271 \\
Total Confrontation & .412 & .597 & .286 \\
\hline Total Trust & .444 & -.567 & .044 \\
\hline Total Authenticity & .238 & .061 &. $\mathbf{8 0 5}$ \\
Total Proaction & .738 & .244 & .118 \\
\hline Total Autonomy & .718 & .157 & -.130 \\
\hline Total Collaboration & .174 & $\mathbf{. 6 1 9}$ & -.507 \\
\hline Total Experimentation & .630 & -.514 & -.133 \\
\hline Extraction Method: Principal Compont Anal
\end{tabular}

Extraction Method: Principal Component Analysis.

a. 3 components extracted. 
Interpretations: The component matrix gives the factor loadings. This is the central output for factor analysis. Loadings above 0.6 are usually considered "high" and those below 0.4 are "low". In the component matrix given "Proaction" is associated strongly with the first factor, "Collaboration" is associated strongly with the second factor and "Authenticity" is associated strongly with the third factor.

\section{FINDINGS}

Table-12. Overall Mean of the Parameters

\begin{tabular}{lll}
\hline Parameters & Mean & Std. Deviation \\
\hline Total Openness & 2.722 & 0.94977 \\
\hline Total Confrontation & 2.7593 & 0.96523 \\
\hline Total Trust & 2.7559 & 0.90431 \\
\hline Total Authenticity & 2.4847 & 0.89534 \\
\hline Total Proaction & 2.9898 & 0.92393 \\
\hline Total Autonomy & 2.9424 & 0.9073 \\
\hline Total Collaboration & 2.722 & 1.03215 \\
\hline Total Experimentation & 2.5831 & 0.93262 \\
\hline Valid N (list wise) & & \\
\hline
\end{tabular}

Figure-9.

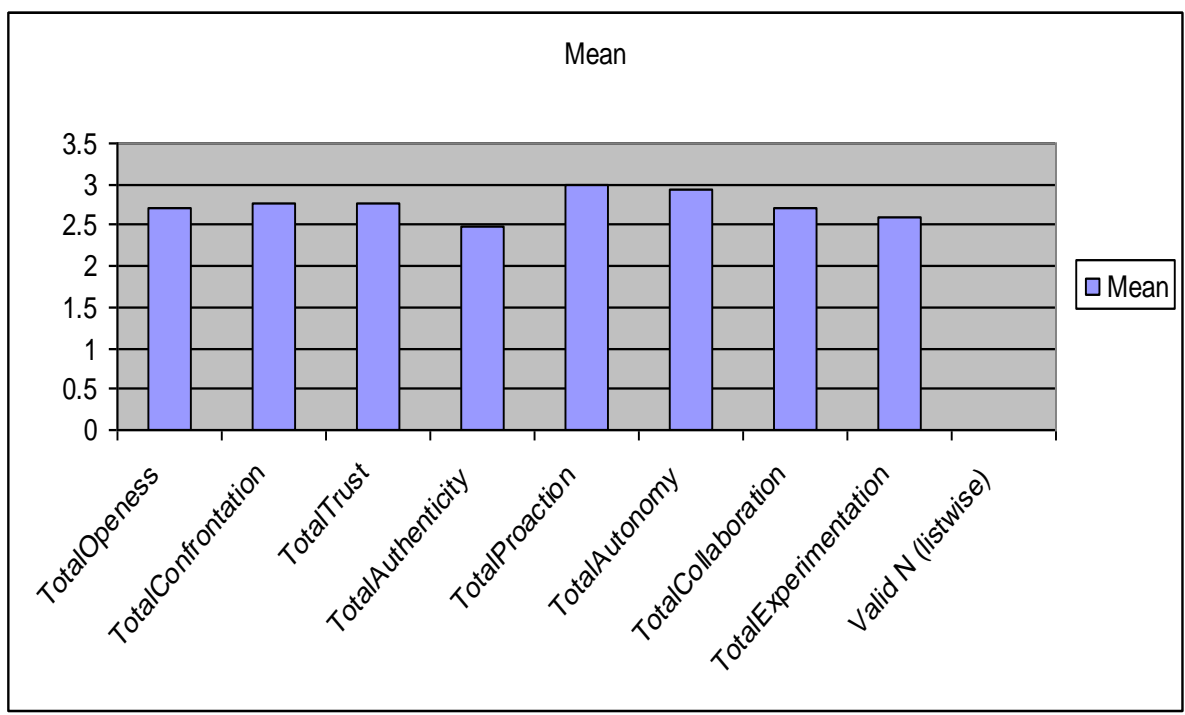

Interpretations: The above table and graph of all parameters show that the mean of all the parameters as a whole lies between 2 and 3 which signifies that the parameters lie between giving a rather low value and a fairly high value. 


\section{RESULTS}

Employees believe that top management gives importance to the human resource and all employees are treated humanely. They also feel that team spirit is in place in the organization which is already by quite a high score on the collaboration aspect.

The climate is also favourable in terms of employee being handled with care by seniors as they understand the mistake and do not take any strict disciplinary action such as punishing or discouraging.

There is also fair share of management involvement in making work enjoyable as employees have high expectation from management, seniors regarding development of employees.

There is open discussion on problems and solution. Since team spirit is a kind of organization's culture, employees are helpful to each other. However, having supportive climate among employees and from management employees does not seem to be helping employees to be proactive in self-development. It seems they like to be taken care by the management rather than being explorative for one's professional development.

Good part of Spanco regarding HRD is that top management understands the importance of human resource and actually translates that realization into day to day practice and HR policies.

For HRD climate to be positive or encouraging it is always a must that top management understands the importance of HR and workforce has team spirit. In this regard, the organization has a good base and all it needs to do is built upon its strong foundation. It also shows that there is an involvement of top management and mid-level management in HRD efforts.

However, despite the support from seniors, employees seem to have dependent attitude or have high expectation from their seniors about self-development and they expect to be looked after rather than being proactive themselves. There was also good response on employees taking initiative for self-development.

\section{CONCLUSIONS}

In conclusion, the overall HRD climate of Spanco is encouraging. There is a keen interest of top management in HRD and there is a high team spirit and employees take training seriously. Also training transfer is in practice and organizational belonging of employees is high. Despite of such positive base for HRD to take up in a highly professional manner, HRD mechanism needs improvisation in a systematic way. Spanco also needs to focus on staff for the motivation since OCTAPACE perceived by this level is comparatively low. Various HRD systems needs to be introduced such as training plan for regular staff, career development, incentive scheme, training effectiveness evaluation, fair promotional system so that HRD climate of Spanco will be more supportive on the middle and top level staff. 


\section{REFERENCES}

Alvesson, M., 2002. Understanding organizational culture. Thousand Oaks: CA: Sage.

Connell, W., D. Papke, R. Stanton and S. Wise, 2003. Diagnosing the learning capacity of a financial service institution. In S. A. Lynham \& T. M. Egan (Eds.). Academy of Human Resource Development 2003 Conference Proceedings. Bowling Green, OH: AHRD, pp: 529-536.

Deal, T.E. and A.A. Kennedy, 1982. Corporate cultures: The rites and rituals of corporate life. Reading, MA: Addison-Wesley.

Denison, D.R., 1990. Corporate culture and organizational effectiveness. New York: John Wiley \& Sons.

Hansen, C.G. and W.M. Kahnweiler, 1994. Organizational and occupational cultures: A comparative inquiry through organizational stories. In A. Brooks \& K. Watkins (Eds.), Academy of Human Resource Development 1994 Proceedings. Austin, TX: AHRD, pp: 72-78.

Hatcher, T., 2000. A study of the influence of the theoretical foundations of human resource development on research and practice. In K. P. Kuchinke (Ed.), Academy of HumanResource Development 2000 Conference Proceedings (paper 2-2). Baton Rouge, LA: AHRD.

Kuchinke, P., 2001. Institutional and curricular characteristics of learning graduate HRD programs in the U.S. In O. A. Aliaga (Ed.), Academy of Human Resource Development 2001 Conference Proceedings (paper 20-1). Baton Rouge, LA: AHRD.

Maria, R.F.S. and K.E. Watkins, 2001. Perceptions of learning culture and concerns about the innovation on use of innovation: A question of level of analysis. In $\mathrm{O}$. A. Aliaga (Ed.), Academy of Human Resource Development 2001 Conference Proceedings (paper 36-1). Baton Rouge, LA: AHRD.

Martin, J., 2002. Organizational culture: Mapping the terrain. Thousand Oaks: CA: Sage.

O'Reilly, C., 1989. Corporations, culture, and commitment: Motivation and social control in organizations. California Management Review, 31 (4): 9-25.

Ouchi, W.G., 1981. Theory Z: How American business can meet the Japanese challenge. Reading, MA: Addison-Wesley Publishing Company.

Peters, T.J. and R.H. Waterman, 1982. In search of excellence: Lessons from America's bestrun companies. New York: Harper \& Row.

Powell, T., 1997. The impact of organizational sub-cultures on information sharing: A manufacturing company's dilemma. In Academy of Human Resource Development 2001Conference Proceedings (paper 6-1). Baton Rouge, LA: AHRD.

Shafritz, J.M., J.S. Ott and Y.S. Jang, 2005. Classics of organizational theory. 6th Edn., Belmont, CA: Thomson Wadsworth. 
Turnbull, S., 2001. The planned and unintended emotions by a corporate change programme: Managing the gaps and their implications for HRD practice. In O. A. Aliaga (Ed.), Academy of Human Resource Development 2001 Conference Proceedings (paper 28-2). Baton Rouge, LA: AHRD.

Walton, J.S. and P.K. Basra, 2001. Continuous improvement through TQM - A case study in rhetoric. In O. A. Aliaga (Ed.), Academy of Human Resource Development 2001Conference Proceedings (paper 42-3). Baton Rouge, LA: AHRD.

\section{BIBLIOGRAPHY}

Plakhotnik Maria, S. and S. Rocco Tonette, 2005. Organizational culture: A literature review of the AHRD Proceedings, Florida International University, USA. 